\title{
Wpływ wybranych domieszek obniżających gęstość na parametry zaczynu cementowego
}

\section{The effect of selected density-reducing admixtures on cement slurry parameters}

\author{
Marcin Kremieniewski, Miłosz Kędzierski \\ Instytut Nafty i Gazu - Państwowy Instytut Badawczy
}

\begin{abstract}
STRESZCZENIE: Zaczyny lekkie najczęściej stosowane są podczas uszczelniania kolumn rur okładzinowych w warunkach obniżonego ciśnienia złożowego czy w strefach słabozwięzłych. Odpowiednie zmniejszenie gęstości zaczynu umożliwia obniżenie wartości ciśnienia hydrostatycznego, co zapobiega ucieczce zaczynu cementowego w strefy słabo zwięzłe. Dodatkowo, zaczyny o obniżonej gęstości mogą być stosowane w przypadku konieczności podniesienia cementu w przestrzeni pozarurowej na dużą wysokość (głębokie otwory). Podczas opracowywania receptury lekkiego zaczynu cementowego najczęściej stosuje się lekkiego rodzaju dodatki i domieszki, które określane są mianem wypełniaczy. Środki te pozwalają na obniżenie gęstości zaczynu i tym samym zastosowanie go w określonych warunkach geologicznych. Jednakże stosowanie tego rodzaju dodatków i domieszek wywiera znaczny wpływ na parametry technologiczne zarówno świeżego, jak i stwardniałego zaczynu cementowego. W przypadku płynnego zaczynu - obecność lekkich frakcji powoduje zmianę parametrów reologicznych zaczynu, wzrost filtracji czy zmianę wartości odstoju wody. Natomiast płaszcz cementowy powstały z zaczynu lekkiego może posiadać niższe wartości wytrzymałości na ściskanie czy wyższą porowatość. Należy zauważyć, że receptury zaczynów lekkich są najczęściej stosowane do uszczelniania kolumn rur okładzinowych posadowionych na niewielkich głębokościach. Dlatego też istotne jest również uzyskanie odpowiedniego czasu przejścia od punktu początku wiązania do punktu końca wiązania. Przyczynia się to do wyeliminowania możliwości tworzenia się dróg migracji gazu w wiążącym zaczynie cementowym. W związku z powyższym w niniejszej publikacji omówiony został wpływ wybranych domieszek obniżających gęstość na parametry technologiczne zaczynu cementowego. W artykule badaniom poddano 4 rodzaje wypełniaczy (mikrosferę glinokrzemianową dotychczas stosowaną, mikrosferę glinokrzemianową nowej generacji CSF K, mikrosferę szklaną oraz perlit filtracyjny E100F). Wstępne badania przeprowadzone zostały dla zaczynów bazowych składających się tylko z wody i cementu. Wypełniacze lekkie stosowano jako $5 \%$ domieszki do zaczynu. Na tym etapie badaniom poddano czas wiązania płynnego zaczynu oraz wpływ tych domieszek na uzyskane wartości parametrów mechanicznych. W kolejnym etapie przeprowadzono badania dla konkretnego zaczynu cementowego, który zawierał w swoim składzie inne środki, niezbędne do kontrolowania parametrów decydujących o efektywności uszczelniania otworu wiertniczego. W tych recepturach zastosowano $15 \%$ dodatku wytypowanych wypełniaczy lekkich i określono wpływ tych materiałów wypełniających na parametry świeżych i stwardniałych zaczynów cementowych.
\end{abstract}

Słowa kluczowe: zaczyn cementowy, gęstość zaczynu, domieszki lekkie, mikrosfera, perlit, czas wiązania, wytrzymałość na ściskanie, wypełniacze.

ABSTRACT: Lightweight slurries are most commonly used for sealing columns of casing pipes in conditions of reduced reservoir pressure or in low-density zones. Through appropriate reduction of the cement slurry density, the hydrostatic pressure can be lowered, which prevents the cement slurry from escaping into the weakly compacted zones. In addition, cement slurries with reduced density can be used when it is necessary to raise cement in annulus to a large height (deep boreholes). When developing a lightweight cement slurry formula, light additives and admixtures are commonly used as fillers. These measures make it possible to reduce the slurry density and thus to apply it in specific geological conditions. However, the use of such additives and admixtures has a significant impact on the technological parameters of both fresh and hardened cement stone. In the case of fresh cement slurry, the presence of light fractions changes the rheological parameters of the leaven, increases filtration, and changes the water loss value. On the other hand, the cement bond resulting from lightweight slurry may have lower compressive strength values or higher porosity. It should be noted that lightweight slurry formulas are most often used to seal columns of casing pipes installed at small depths. Therefore, it is also important to obtain a proper transition time from the initial setting time to the final setting time. The above contributes to eliminating the possibility of gas migration pathways in the set cement slurry. In connection with the above, the publication discusses the impact of selected densityreducing admixtures on selected technological parameters of cement slurry. In the article, 4 types of fillers were tested (aluminosilicate

Autor do korespondencji: M. Kremieniewski, e-mail: marcin.kremieniewski@inig.pl

Artykuł nadesłano do Redakcji: 05.12.2019 r. Zatwierdzono do druku: 21.02.2020 r. 
microsphere used so far, new generation aluminosilicate microsphere CSF K, glass microsphere and filter perlite E100F). Initial tests were carried out for base cement slurries consisting only of water and cement. Lightweight fillers were used as a 5\% grout admixture. At this stage, the setting time of fresh cement slurry and the effect of these admixtures on the obtained values of mechanical parameters were tested. In the next stage, tests were carried out for specific cement slurry, which contained other means necessary to control the parameters determining the effectiveness of sealing the borehole. In these recipes, $15 \%$ of the addition of selected lightweight fillers was used and the effect of these filling materials on the parameters of fresh and hardened cement slurries was determined.

Key words: cement slurry, cement slurry density, lightweight admixtures, microsphere, perlite, setting time, compressive strength, fillers.

\section{Wprowadzenie}

Zagadnienie prawidłowego zarurowania i uszczelnienia kolumny eksploatacyjnej nabiera zasadniczego znaczenia na złożach o niskim ciśnieniu złożowym lub w strefach chłonnych. Obecnie technika rurowania i cementowania otworów wiertniczych w warstwach o niskim ciśnieniu złożowym nie ulega zmianie. Różnice występują jednakże w rodzaju stosowanych zaczynów cementowych (Bensted, 2004; Kremieniewski, 2019a; Kremieniewski i Stryczek, 2019). Najczęściej do zmniejszenia wartości gęstości wykorzystywane są różnego rodzaju dodatki redukujące gęstość zaczynów cementowych. Obniżenie gęstości zaczynu pozwala zmniejszyć wartość ciśnienia hydrostatycznego w czasie cementowania, co zapobiega ucieczkom cementu w słabsze strefy (Kremieniewski, 2017b; Jordan et al., 2018; Kremieniewski i Kędzierski, 2019). Zaczyny lekkie stosuje się również w przypadku konieczności podniesienia cementu w przestrzeni pozarurowej na dużą wysokość (dwa zaczyny: górny - lekki i dolny - o normalnej gęstości) lub do prac rekonstrukcyjnych odwiertu. Niestety podczas projektowania tego rodzaju zaczynów, powstały z nich płaszcz cementowy charakteryzuje się niskimi wartościami parametrów mechanicznych, co jest jeszcze częściej obserwowane po krótkim czasie hydratacji od 24 do 48 godzin (Bayu et al. 2010; Kremieniewski, 2018, 2019d). Dlatego też istotnym czynnikiem jest odpowiedni dobór zarówno ilościowy, jak i jakościowy dodatków i domieszek obniżających gęstość zaczynu. Umożliwia to uzyskanie wymaganej, dostosowanej do warunków geologiczno-złożowych gęstości zaczynu przy jednoczesnym zachowaniu optymalnych wartości parametrów mechanicznych tworzącego się płaszcza cementowego (Nelson, 1990; Rzepka i Stryczek, 2008).

Jednym z wielu rodzajów środków, które są stosowane w celu opracowania lekkiego zaczynu o obniżonej gęstości są wypełniacze. Zastosowanie takiego materiału pozwala na wyeliminowanie ucieczek cementu w słabsze strefy i możliwe jest wykonanie mniejszej liczby stopni cementowań (Raczkowski et al., 1978; Nelson, 1990; Kremieniewski et al., 2017). Czasami wypełniacze stosowane są również w celu zwiększenia wytrzymałości strukturalnej zaczynów, co pozwala na zastosowanie mniejszej ilości cementu w zaczynie przy jednoczesnym zachowaniu tej samej objętości zaczynu. $\mathrm{Z}$ jednej strony jest to pewnego rodzaju sposób na obniżenie kosztów cementowania, a z drugiej na obniżenie gęstości zaczynu. Wypełniacze można podzielić na trzy kategorie w zależności od mechanizmu obniżania gęstości. Pierwszym rodzajem wypełniaczy są wypełniacze wodne, np. gliny oraz środki zagęszczające, które pozwalają na zwiększenie współczynnika wodnego. Drugim rodzajem wypełniaczy są zespoły o niskiej gęstości nasypowej, czyli wartości niższej niż gęstość nasypowa cementu, która wynosi około $3150 \mathrm{~kg} / \mathrm{m}^{3}$. Trzecim rodzajem są wypełniacze gazowe (Nelson, 1990; Kremieniewski, 2017a). Ze względu na to, że najczęściej stosowane w sektorze naftowym są zespoły o niskiej gęstości, to na tego rodzaju środkach skoncentrowano się w dalszej części publikacji.

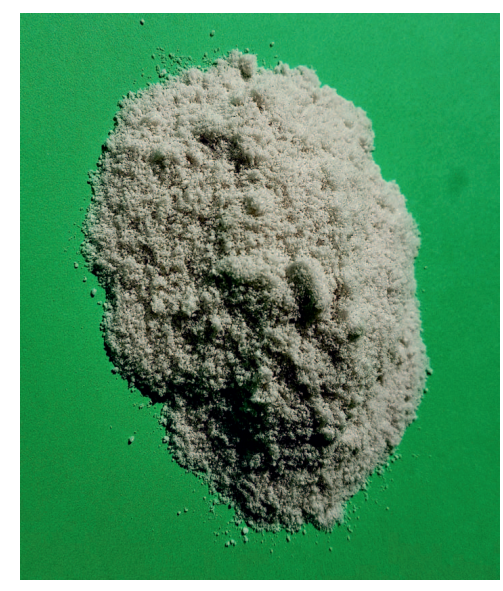

Rys. 1. Próbka perlitu

Fig. 1. Perlite sample

Jednym z głównych wypełniaczy stosowanych podczas opracowywania lekkich zaczynów cementowych są dodatki lekkie, a środkiem należącym do tej grupy jest perlit. Stanowi on głównie kruszone szkło wulkaniczne (rys. 1), które po podgrzaniu do temperatury początkowej fuzji zwiększa swoją objętość (Stryczek et al., 2009; Kremieniewski, 2017b). Struktura porowa perlitu charakteryzuje się obecnością zarówno porów otwartych, jak i zamkniętych. Pod wpływem działania ciśnienia hydrostatycznego pory otwarte zostają wypełnione cieczą, natomiast pory zamknięte ulegają destrukcji. W związku z powyższym projektując zaczyn cementowy z dodatkiem perlitu jako głównego środka obniżającego gęstość zaczynu należy przyjąć, że jego gęstość przy ciśnieniu atmosferycznym będzie niższa niż założona i wymagana gęstość w otworze. 
Na rysunku 2 przedstawiono zakres gęstości zaczynu z dodatkiem perlitu przy ciśnieniu atmosferycznym. Rysunek 3 przedstawia natomiast zakres gęstości zaczynów lekkich z dodatkiem perlitu przy ciśnieniu $21 \mathrm{MPa}$ (Nelson, 1990). Innego rodzaju środkiem często stosowanym w celu obniżenia gęstości zaczynu cementowego są mikrosfery. Są to materiały kuliste o gęstości nasypowej od $400 \mathrm{~kg} / \mathrm{m}^{3}$ do $600 \mathrm{~kg} / \mathrm{m}^{3}$, które posiadają wnętrze wypełnione gazem.

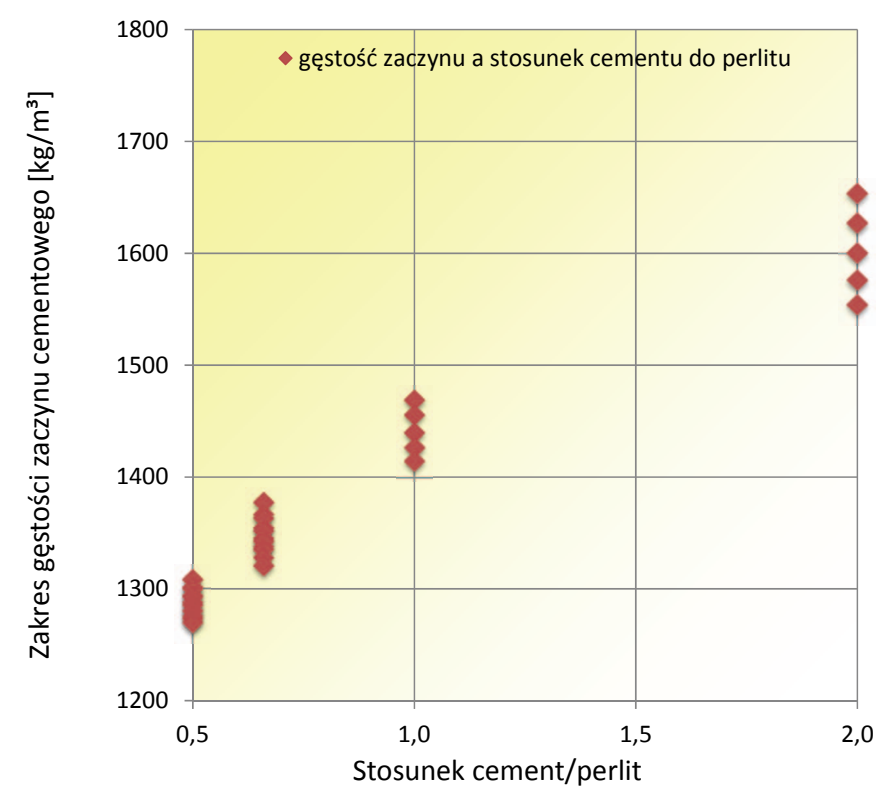

Rys. 2. Zakres gęstości zaczynu przy różnych proporcjach mieszanin cementu do perlitu - wyniki przy ciśnieniu atmosferycznym

Fig. 2. Slurry density range at different proportions of cement/ perlite mixtures - results at atmospheric pressure

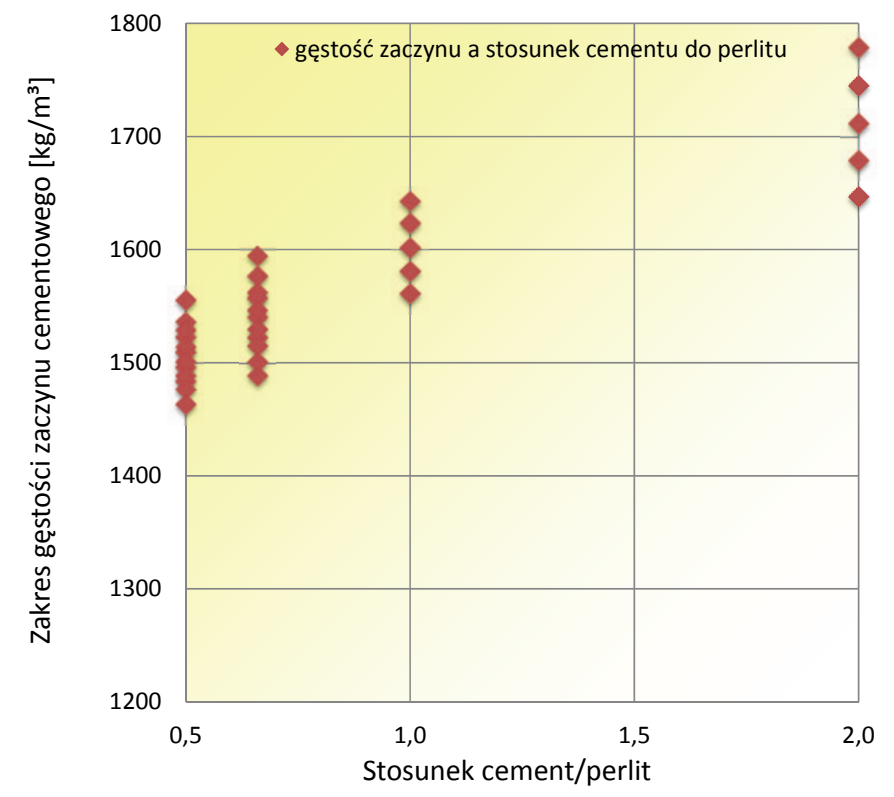

Rys. 3. Zakres gęstości zaczynu przy różnych proporcjach mieszanin cementu do perlitu - wyniki przy ciśnieniu około 21 MPa

Fig. 3. Slurry density range at different proportions of cement/ perlite mixtures - results at a pressure of about $21 \mathrm{MPa}$
Dodatek mikrosfery do zaczynu cementowego pozwala na bardzo mocne obniżenie jego gęstości przy jednoczesnym zachowaniu dobrej wytrzymałości oraz niskiej przepuszczalności (Nelson, 1990; Stryczek et al., 2005; 2016). Wyróżnia się mikrosferę ceramiczną (rys. 4), która jest pochodną pyłów piecowych oraz mikrosferę szklaną. Zaczyny cementowe z dodatkiem mikrosfery w pewnych okolicznościach pozwalają na wyeliminowanie metody cementowania wielostopniowego (Nelson, 1990; Uliasz i Dubiel, 2015). Pewnego rodzaju ograniczeniem w stosowaniu mikrosfery ceramicznej jest jej niska odporność na ciśnienie hydrostatyczne, dlatego też dodatek ten nie może być stosowany w zaczynach projektowanych do uszczelniania głębokich otworów (Półchłopek et al., 1993; Rzepka et al., 2012; Kremieniewski i Rzepka, 2016). Mikrosfery ceramiczne ulegają zgniataniu pod wpływem ciśnienia, wskutek czego wzrasta gęstość zaczynu. Taki wzrost gęstości przedstawiono na rysunku 5. Alternatywą dla mikrosfery ceramicznej jest mikrosfera szklana, która w zależności od rodzaju charakteryzuje się wyższą wytrzymałością mechaniczną, co znajduje przełożenie na większy zakres stosowalności. Ziarna mikrosfery szklanej mają rozmiar od 20 do 200 mikrometrów. Mikrosfery szklane wytrzymują ciśnienia dochodzące do $35 \mathrm{MPa}$ (Herianto i Fathaddin, 2005; Kremieniewski, 2019c). Wadą mikrosfer szklanych jest jednak ich znacznie wyższa cena w porównaniu do mikrosfery ceramicznej.

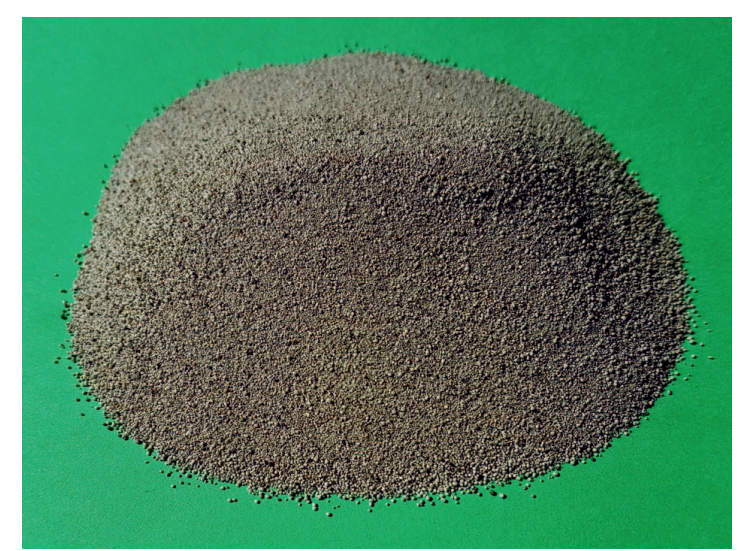

Rys. 4. Próbka mikrosfery ceramicznej

Fig. 4. Ceramic microsphere sample

Dodatki i domieszki (stosowane w celu obniżenia gęstości zaczynu) w znacznym stopniu wpływają na jego parametry technologiczne. Duży wpływ widoczny jest w przypadku wczesnej wytrzymałości na ściskanie, co jest bardzo ważne z punktu widzenia dalszych prac po zabiegu cementowania (Kudowski, 2010; Falode et al., 2013; Kremieniewski, 2019e). W celu określenia wpływu wybranych domieszek obniżających gęstość zaczynu na parametry technologiczne zaczynu, realizuje się szereg badań (Wiśniowski et al., 2007; Peng i Jacobsen 2013; Stryczek et al., 2014; Kremieniewski, 2019b), 


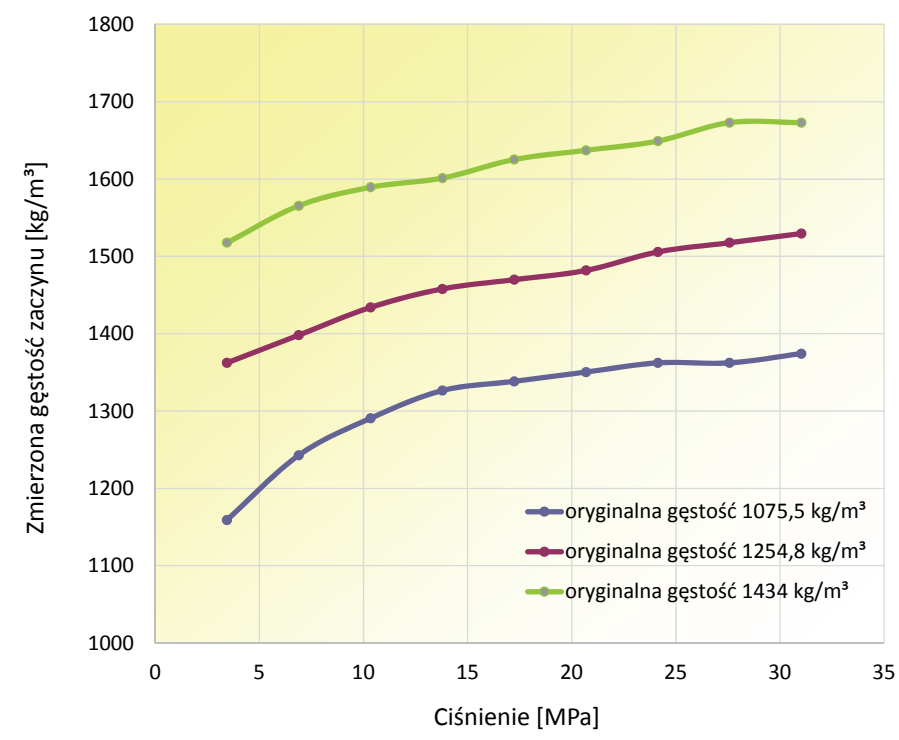

Rys. 5. Gęstość zaczynów cementowych z dodatkiem mikrosfery ceramicznej w zależności od ciśnienia

Fig. 5. Cement slurry density with the addition of ceramic microsphere in relation to pressure

co zostało przedstawione w dalszej części niniejszej publikacji. Na podstawie prowadzonych prac badawczych znacznie łatwiejszym zagadnieniem staje się odpowiedni dobór rodzaju domieszki do zaczynu w celu uzyskania optymalnych wartości parametrów technologicznych projektowanej receptury.

\section{Przebieg prac badawczych}

Badania mające na celu określenie wpływu wybranych domieszek obniżających gęstość zaczynu na parametry zaczynu cementowego, zostały zrealizowane w Laboratorium Zaczynów Uszczelniających INiG - PIB w oparciu o normy: PN-85/G-02320 Cementy i zaczyny cementowe do cementowania w otworach wiertniczych; PN-EN 10426-2 Przemyst naftowy i gazowniczy. Cementy i materialy do cementowania otworów. Część 2: Badania cementów wiertniczych oraz API SPEC 10 Specification for materials and testing for well cements.

Celem cyklu badawczego (który został omówiony w niniejszej publikacji) było wykazanie wpływu wybranych domieszek obniżających gęstość zaczynu na parametry zaczynu cementowego. Zagadnienie to jest bardzo istotne $\mathrm{z}$ praktycznego punktu widzenia, ponieważ receptury zaczynów o obniżonej gęstości przysparzają trudności w odpowiednim doborze parametrów technologicznych dla zaczynu zarówno w fazie płynnej (świeże zaczyny), jak również po związaniu (stwardniałe zaczyny). Związane jest to $\mathrm{z}$ faktem, iż w celu obniżenia gęstości stosuje się znaczne ilości dodatków lekkich. Środki te (w zależności od rodzaju) charakteryzują się zróżnicowanymi właściwościami, a tym samym w zróżnicowany sposób oddziałują na parametry zaczynu.

Omówione w niniejszej publikacji wyniki prac badawczych podzielone zostały na dwa etapy. W pierwszym etapie badaniu poddano cztery rodzaje lekkich wypełniaczy, które stosowano w bazowym ${ }^{1}$ zaczynie cementowym. Na tym etapie określono czas wiązania zaczynu i wytrzymałość na ściskanie po dwóch dniach hydratacji próbki. W drugim etapie określono wpływ dodatków lekkich na parametry konkretnego zaczynu przeznaczonego do stosowania w warunkach otworowych dla temperatury $30^{\circ} \mathrm{C}$ i ciśnienia $5 \mathrm{MPa}$. Na tym etapie zmierzono gęstość, parametry reologiczne zaczynu, filtrację i czas gęstnienia. Dla stwardniałego zaczynu przeprowadzono natomiast badania wczesnej wytrzymałości na ściskanie po 12 , 24 i 48 godzinach hydratacji próbki oraz określono czas, po jakim próbka osiągnie wytrzymałość 3,5 MPa, która to wartość jest niezbędna do prowadzenia dalszych prac po wykonaniu zabiegu cementowania.

Podczas badań wpływu wypełniaczy lekkich na parametry normowych zaczynów wykonano badania dla pięciu receptur. Pierwsza receptura to zaczyn kontrolny, który nie zawierał wypełniacza lekkiego. Badane zaczyny sporządzono na bazie cementu portlandzkiego klasy CEM 42,5 i zawierały $1,5 \%$ (bwoc) chlorku wapnia w celu przyspieszenia wiązania. Wypełniaczami lekkimi czterech kolejnych zaczynów były: mikrosfera glinokrzemianowa, mikrosfera CSF K, mikrosfera szklana H5 oraz perlit filtracyjny E100F. Domieszki lekkie stosowano w ilości 5\% w stosunku do masy cementu. Zaczyny sporządzono na wodzie wodociągowej, a współczynnik wodno cementowy wszystkich receptur wynosił 0,5 . Składy i uzyskane wyniki badań zestawiono w tabeli 1 .

Analizując uzyskane wyniki badań czasu wiązania stwierdzono, że 5\%-owy udział domieszki badanych wypełniaczy lekkich powoduje skrócenie zarówno czasu początku wiązania, jak i czasu końca wiązania, co obserwowane jest na rysunku 6. Przy czym najmocniejsze skrócenie czasu wiązania odnotowano po zastosowaniu perlitu filtracyjnego. Początek wiązania uzyskano po 90 minutach, a koniec wiązania po czasie 138 minut. Natomiast czas wiązania zaczynu kontrolnego wynosił 261 minut dla początku wiązania oraz 473 minuty dla punktu, w którym odnotowano koniec wiązania. Tak mocne skrócenie czasu wiązania po wprowadzeniu perlitu filtracyjnego może być efektem wzrostu zapotrzebowania na wodę do hydratacji cementu na skutek obecności tej domieszki, co jednocześnie wywarło wpływ na czas wiązania. $Z$ kolei analizując wpływ domieszek wypełniaczy lekkich na wytrzymałość

\footnotetext{
${ }^{1}$ Zaczyn bazowy - zaczyn składający się z wody i cementu o współczynniku wodno cementowym $(\mathrm{w} / \mathrm{c}=0,50)$.
} 
Tabela 1. Badania różnego rodzaju domieszek obniżających gęstość zaczynu (spoiwo wiążące - cement CEM 42,5)

Table 1. Tests on various types of admixtures that reduce cement slurry density (binding binder - CEM 42.5 cement)

\begin{tabular}{|c|c|c|c|c|c|c|c|}
\hline \multirow{3}{*}{$\begin{array}{l}\mathrm{Nr} \\
\text { próbki }\end{array}$} & \multirow{3}{*}{$\begin{array}{c}\text { Rodzaj cementu } \\
\text { Wspólczynnik } \\
\text { wodno-cementowy } \\
\text { Koncentracja } \mathrm{CaCl}_{2}\end{array}$} & \multirow{3}{*}{$\begin{array}{c}\text { Udzial } \\
\text { cementu }\end{array}$} & \multirow{3}{*}{$\begin{array}{c}\text { Rodzaj } \\
\text { domieszki }\end{array}$} & \multirow[b]{2}{*}{$\begin{array}{c}\text { Udzial } \\
\text { domieszki }\end{array}$} & \multicolumn{2}{|c|}{ Czas wiązania } & \multirow{2}{*}{$\begin{array}{c}\text { Wytrzymałość na } \\
\text { ściskanie (średnia } \\
\text { arytmetyczna) } \\
2 \text { dni hydratacji }\end{array}$} \\
\hline & & & & & $\begin{array}{l}\text { początek } \\
\text { wiązania } \\
\text { PW }\end{array}$ & $\begin{array}{c}\text { koniec } \\
\text { wiązania } \\
\text { KW }\end{array}$ & \\
\hline & & & & {$[\%]$} & [minuty] & [minuty] & [MPa] \\
\hline 1 & 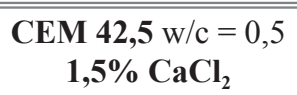 & 100 & - & 0,0 & 261 & 473 & 18,0 \\
\hline 2 & $\begin{array}{c}\mathrm{CEM} 42,5 \mathrm{w} / \mathrm{c}=0,5 \\
1,5 \mathrm{CaCl}_{2}\end{array}$ & 100 & $\begin{array}{l}\text { mikrosfera zwykła } \\
\text { (glinokrzemianowa) }\end{array}$ & 5,0 & 210 & 268 & 15,5 \\
\hline 3 & $\begin{array}{c}\mathrm{CEM} 42,5 \mathrm{w} / \mathrm{c}=0,5 \\
1,5 \mathrm{CaCl}_{2}\end{array}$ & 100 & mikrosfera CSF K & 5,0 & 211 & 269 & 20,0 \\
\hline 4 & $\begin{array}{c}\mathrm{CEM} 42,5 \mathrm{w} / \mathrm{c}=0,5 \\
1,5 \mathrm{CaCl}_{2}\end{array}$ & 100 & mikrosfera szklana H5 & 5,0 & 150 & 206 & 24,0 \\
\hline 5 & $\begin{array}{c}\mathrm{CEM} 42,5 \mathrm{w} / \mathrm{c}=0,5 \\
1,5 \mathrm{CaCl}_{2}\end{array}$ & 100 & perlit filtracyjny E100F & 5,0 & 90 & 138 & 25,0 \\
\hline
\end{tabular}

na ściskanie po dwóch dniach hydratacji stwierdzono wzrost wartości analizowanego parametru (w stosunku do zaczynu kontrolnego $18 \mathrm{MPa}$ ) dla wszystkich wypełniaczy z wyjątkiem mikrosfery glinokrzemianowej. Pod wpływem tej domieszki wartość wytrzymałości uległa obniżeniu do 15,5 MPa. Najmocniejszy przyrost wytrzymałości na ściskanie uzyskano po wprowadzeniu perlitu filtracyjnego oraz mikrosfery szklanej (rys. 7). Takie zachowanie może mieć związek z przyśpieszonym procesem hydratacji w początkowym okresie, co znajduje potwierdzenie podczas wcześniej omówionego badania czasu wiązania.

W kolejnym teście przeprowadzono analogiczne pomiary dla takich samych zaczynów - jedyną różnicą było użycie większej, bo 3\%-owej koncentracji chlorku wapnia. Działanie takie podyktowane było najczęstszym zakresem stosowania koncentracji $\mathrm{CaCl}_{2}$ w przedziale od $1,5 \%$ do $3 \% \mathrm{w}$ warunkach otworowych. Składy i wyniki badań zestawiono w tabeli 2. Analizując uzyskane wyniki badań stwierdzono, że 5\%-owa obecność mikrosfery glinokrzemianowej i mikrosfery CSF K (inna odmiana mikrosfery glinokrzemianowej) w zaczynie zawierającym $3 \% \mathrm{CaCl}_{2}$ nie powodowała skrócenia czasu wiązania. Uzyskane wartości były porównywalne (różnice do około 10 minut) (rys. 8). Pod wpływem mikrosfery szklanej odnotowano skrócenie wartości czasu końca wiązania. Jedynie wprowadzenie perlitu filtracyjnego spowodowało mocniejsze skrócenie zarówno czasu początku, jak i końca wiązania (rys. 8). Natomiast podczas badania wczesnej wytrzymałości na ściskanie zaobserwowano mniej wyraźny przyrost wartości w zaczynach zawierających 3\% chlorku wapnia i z domieszką wypełniaczy lekkich niż w przypadku zaczynów zawierających $1,5 \% \mathrm{CaCl}_{2}$. W recepturach $\mathrm{z}$ dodatkiem $3 \% \mathrm{CaCl}_{2}$ najmocniejszy przyrost wytrzymałości na ściskanie uzyskano po wprowadzeniu domieszki mikrosfery CSF K (rys. 9).

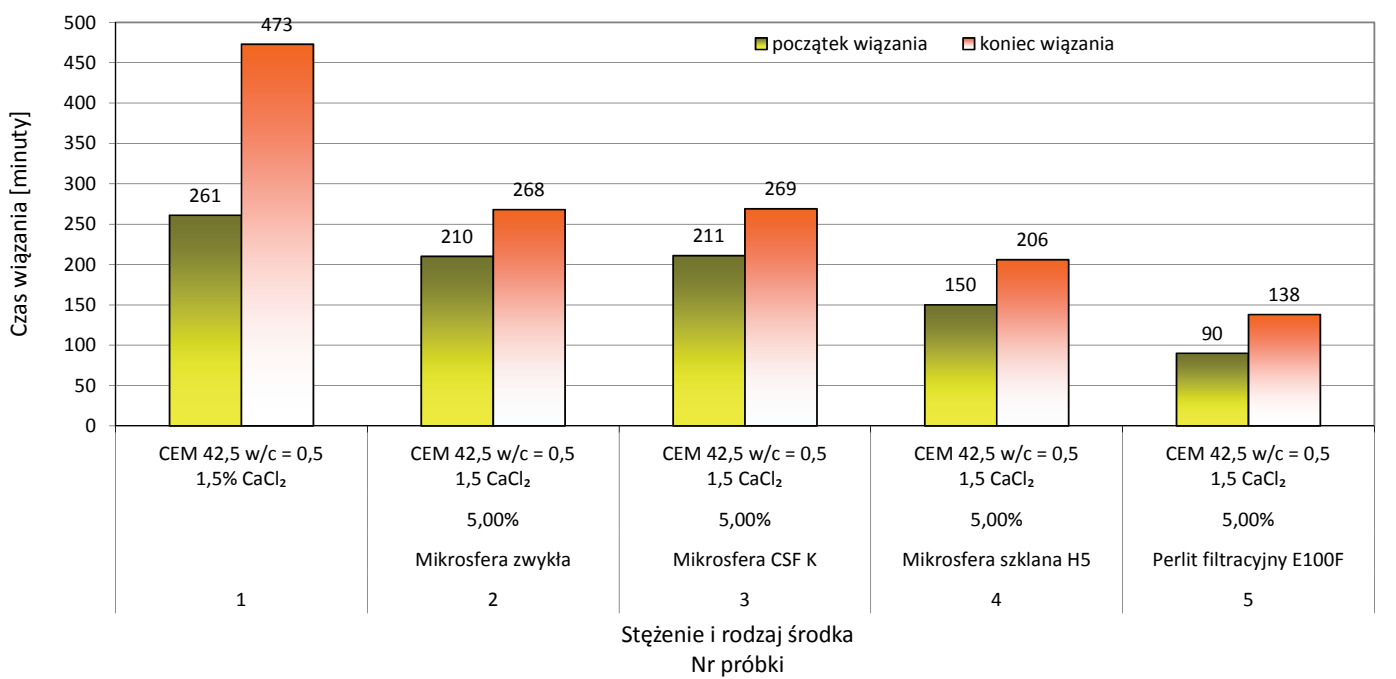

Rys. 6. Zestawienie czasu początku wiązania i czasu końca wiązania badanych próbek z dodatkami obniżającymi gęstość zaczynu (spoiwo wiążące - cement CEM 42,5, przyspieszacz wiązania $\left.1,5 \% \mathrm{CaCl}_{2}\right)$

Fig. 6. Comparison of initial and final setting time of the tested samples with additives reducing the slurry density (binding binder - CEM 42.5 cement, binding accelerator $1.5 \% \mathrm{CaCl}_{2}$ ) 


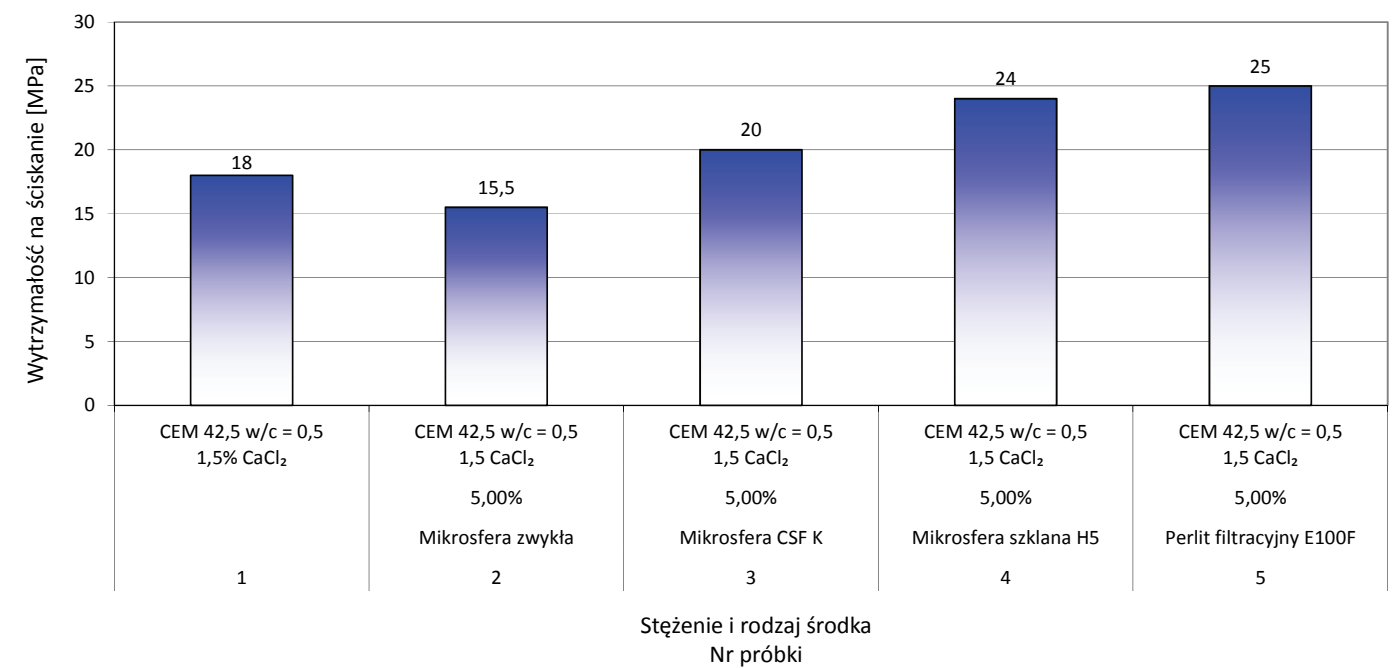

Rys. 7. Zestawienie wytrzymałości na ściskanie dla próbek z dodatkami obniżającymi gęstość zaczynu (spoiwo wiążące - cement CEM 42,5 , przyspieszacz wiązania $1,5 \% \mathrm{CaCl}_{2}$ )

Fig. 7. Compression of the compressive strength for specimens with additives reducing cement slurry density (binder - CEM 42.5 cement, $1.5 \% \mathrm{CaCl}_{2}$ setting accelerator)

Tabela 2. Badania różnego rodzaju dodatków obniżających gęstość zaczynu (spoiwo wiążące - cement CEM 42,5; 3,0\% CaCl ${ }_{2}$ )

Table 2. Tests on various types of additives reducing cement slurry density (binder - CEM 42.5 cement; $3.0 \% \mathrm{CaCl}_{2}$ )

\begin{tabular}{|c|c|c|c|c|c|c|c|}
\hline \multirow{3}{*}{$\begin{array}{l}\mathrm{Nr} \\
\text { próbki }\end{array}$} & \multirow{3}{*}{$\begin{array}{c}\text { Rodzaj cementu } \\
\text { Współczynnik } \\
\text { wodno-cementowy } \\
\text { Koncentracja } \mathrm{CaCl}_{2}\end{array}$} & \multirow{3}{*}{$\begin{array}{c}\text { Udzial } \\
\text { cementu }\end{array}$} & \multirow{3}{*}{$\begin{array}{c}\text { Rodzaj } \\
\text { domieszki }\end{array}$} & \multirow[b]{2}{*}{$\begin{array}{c}\text { Udzial } \\
\text { domieszki }\end{array}$} & \multicolumn{2}{|c|}{ Czas wiązania } & \multirow{2}{*}{$\begin{array}{c}\text { Wytrzymałość na } \\
\text { ściskanie (średnia } \\
\text { arytmetyczna) } \\
2 \text { dni hydratacji }\end{array}$} \\
\hline & & & & & $\begin{array}{c}\text { początek } \\
\text { wiązania } \\
\text { PW }\end{array}$ & $\begin{array}{c}\text { koniec } \\
\text { wiązania } \\
\text { KW }\end{array}$ & \\
\hline & & & & {$[\%]$} & [minuty] & [minuty] & [MPa] \\
\hline 6 & $\begin{array}{c}\mathrm{CEM} 42,5 \mathrm{w} / \mathrm{c}=0,5 \\
3,0 \% \mathrm{CaCl}_{2}\end{array}$ & 100 & - & 0,0 & 141 & 229 & 15,0 \\
\hline 7 & $\begin{array}{c}\mathrm{CEM} 42,5 \mathrm{w} / \mathrm{c}=0,5 \\
3,0 \mathrm{CaCl}_{2}\end{array}$ & 100 & mikrosfera zwykła & 5,0 & 150 & 228 & 15,5 \\
\hline 8 & $\begin{array}{c}\mathrm{CEM} 42,5 \mathrm{w} / \mathrm{c}=0,5 \\
3,0 \mathrm{CaCl}_{2}\end{array}$ & 100 & mikrosfera CSF K & 5,0 & 151 & 239 & 20,5 \\
\hline 9 & $\begin{array}{c}\text { CEM 42,5 w/c }=0,5 \\
3,0 \mathrm{CaCl}_{2}\end{array}$ & 100 & mikrosfera szklana H5 & 5,0 & 132 & 184 & 19,5 \\
\hline 10 & $\begin{array}{c}\text { CEM } 42,5 \mathrm{w} / \mathrm{c}=0,5 \\
3,0 \mathrm{CaCl}_{2}\end{array}$ & 100 & perlit filtracyjny E100F & 5,0 & 92 & 160 & 19,0 \\
\hline
\end{tabular}

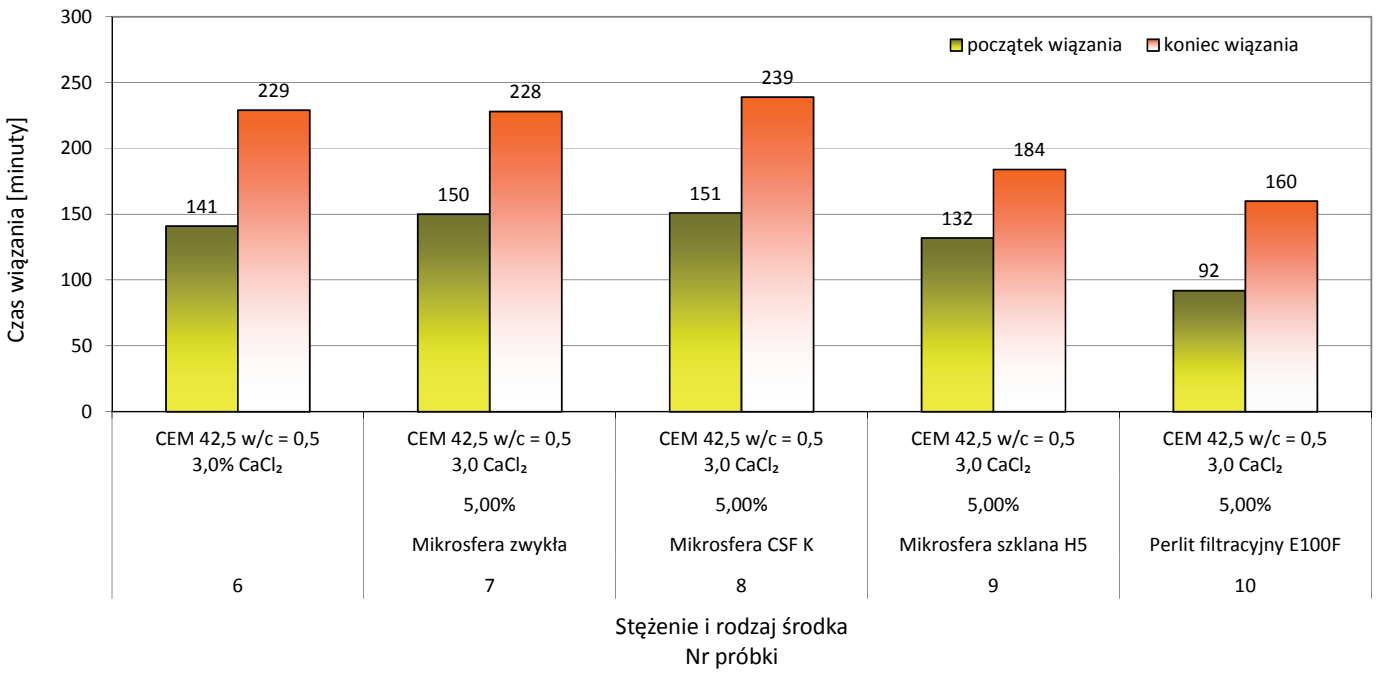

Rys. 8. Zestawienie czasu początku wiązania i czasu końca wiązania badanych próbek z dodatkami obniżającymi gęstość zaczynu (spoiwo wiążące - cement CEM 42,5; przyspieszacz wiązania $3,0 \% \mathrm{CaCl}_{2}$ )

Fig. 8. Comparison of the initial and final setting time of tested samples with additives reducing the cement slurry density (binding binder - CEM 42.5 cement; setting accelerator $3.0 \% \mathrm{CaCl}_{2}$ )

W drugim etapie badań nad wpływem domieszek obniżających gęstość zaczynu na wybrane parametry zaczynu cementowego do testów poddano cztery receptury zaczynów, gdzie punktem odniesienia był zaczyn zawierający mikrosferę glinokrzemianową dotychczas stosowaną w warunkach przemysłowych (skład nr 11; tab. 3). Badania zostały przeprowadzone dla receptur zaczynów przeznaczonych do uszczelniania otworów w warunkach geologiczno-złożowych (temp. $30^{\circ} \mathrm{C}$ i ciśnienie $5 \mathrm{MPa}$ ). 


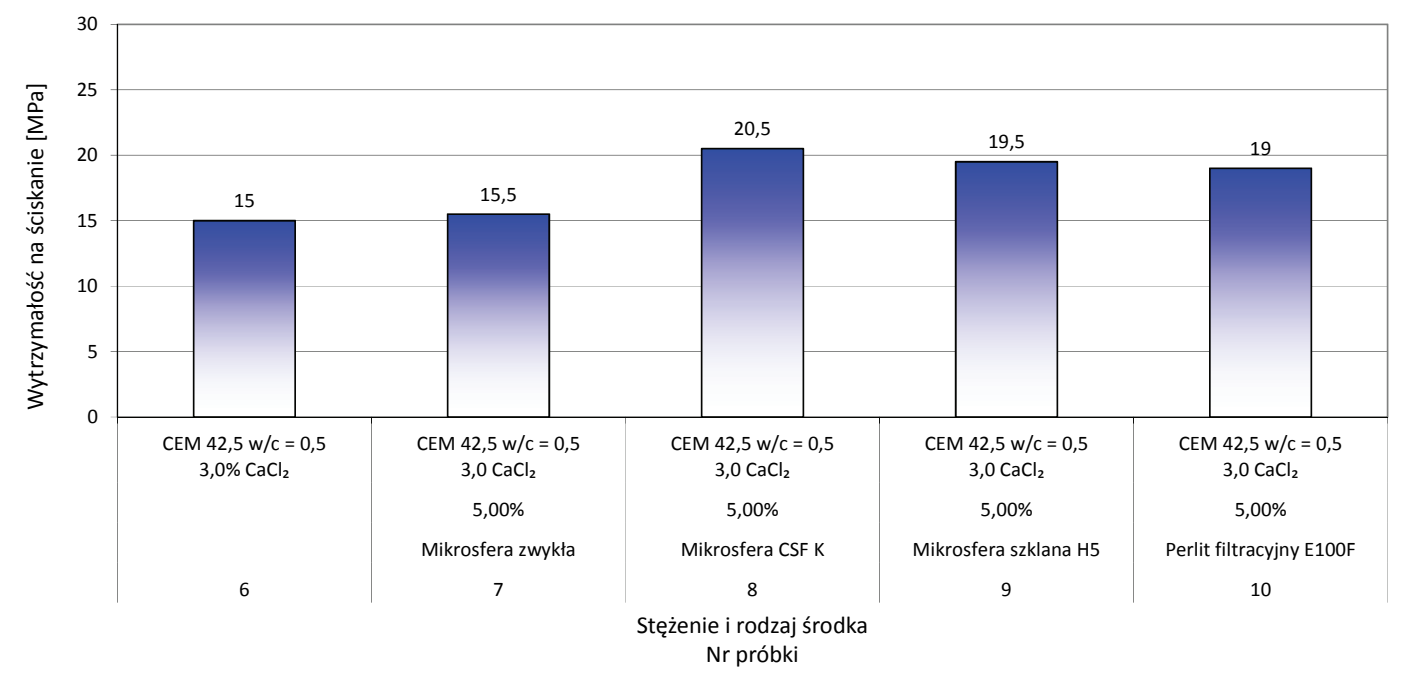

Rys. 9. Zestawienie wytrzymałości na ściskanie dla próbek z dodatkami obniżającymi gęstość zaczynu (spoiwo wiążące - cement CEM 42,5; przyspieszacz wiązania $3,0 \% \mathrm{CaCl}_{2}$ )

Fig. 9. Comparison of the compressive strength list for specimens with additives that reduce slurry density (binder - CEM 42.5 cement; setting accelerator $3.0 \% \mathrm{CaCl}_{2}$ )

Tabela 3. Receptury zaczynów cementowych dla warunków otworowych zawierających wytypowane domieszki (składniki stałe): cement CEM I 42,5 $=100 \%$, bentonit $=1,5 \%\left(\right.$ bwow $\left.^{21}\right)$, środek odpieniający $=0,5 \%\left(\right.$ bwoc $\left.^{32}\right)$, środek antyfiltracyjny $=0,3 \%($ bwoc $)$, $\mathrm{CaCl}_{2}=3,0 \%$ (bwoc), mikrocement $10,0 \%$

Table 3. Cement slurry recipes for well conditions containing selected admixtures (solid components): CEM I cement $42.5=100 \%$, bentonite $=1.5 \%$ (bwow), defoaming agent $=0.5 \%$ (bwoc), anti-filtration agent $=0.3 \%$ (bwoc), $\mathrm{CaCl}_{2}=3.0 \%$ (bwoc), microcement $10.0 \%$

\begin{tabular}{|c|c|c|c|c|c|c|c|}
\hline $\begin{array}{c}\text { Skład (Nr); } \\
\text { współczynnik (w/c) }\end{array}$ & $\begin{array}{c}\text { Środek } \\
\text { upłynniający }\end{array}$ & Lateks & $\begin{array}{c}\text { Stabilizator } \\
\text { lateksu }\end{array}$ & Mikrosfera & $\begin{array}{c}\text { Mikrosfera } \\
\text { CSF K }\end{array}$ & $\begin{array}{c}\text { Mikrosfera } \\
\text { szklana H5 }\end{array}$ & $\begin{array}{c}\text { Perlit filtracyjny } \\
\text { E100F }\end{array}$ \\
\hline \hline $\mathrm{Nr} 11 ; \mathrm{w} / \mathrm{c}=0,75$ & 0,2 & 5,0 & 0,5 & 15,0 & - & - & - \\
\hline $\mathrm{Nr} 12 ; \mathrm{w} / \mathrm{c}=0,75$ & 0,2 & 5,0 & 0,5 & - & 15,0 & - & - \\
\hline $\mathrm{Nr} 13 ; \mathrm{w} / \mathrm{c}=0,85$ & 0,3 & 5,0 & 0,5 & - & - & 15,0 & - \\
\hline $\mathrm{Nr} 14 ; \mathrm{w} / \mathrm{c}=0,85$ & 0,3 & 5,0 & 0,5 & - & - & - & 15,0 \\
\hline
\end{tabular}

Wszystkie zaczyny zawierały składniki o takich samych koncentracjach: 1,5\% (bwow) bentonitu, 0,5\% (bwoc) środek odpieniający, środek antyfiltracyjny w koncentracji 0,3\% (bwoc), 3,0 \% (bwoc) chlorku wapnia oraz 10\%-owy dodatek mikrocementu. Dodatkowo zaczyny posiadały $5 \%$ lateksu i stabilizator. Zmienną były rodzaje zastosowanych dodatków lekkich, które zastosowano w koncentracji 15\% w stosunku do masy cementu. Składy receptur zestawiono w tabeli 3.

Po sporządzeniu zaczynów przystąpiono do badań parametrów technologicznych świeżych i stwardniałych zaczynów. Analizując zestawione wyniki (rys. 10) stwierdzono, że gęstość zaczynów zawierała się w wąskim przedziale od $1450 \mathrm{~kg} / \mathrm{m}^{3}$ dla zaczynu bazowego (nr 11) do $1480 \mathrm{~kg} / \mathrm{m}^{3}$ dla zaczynu $\mathrm{z}$ dodatkiem perlitu filtracyjnego (nr 14). Natomiast znacznie niższą gęstość posiadał zaczyn, którego skład wzbogacono $15 \%$-owym dodatkiem mikrosfery szklanej (nr 13) i uzyskano gęstość $1300 \mathrm{~kg} / \mathrm{m}^{3}$. Powyższe mogło być spowodowane znacznie większą powierzchnią właściwą mikrosfer szklanych. Podczas weryfikacji parametrów reologicznych zestawionych w tabeli 4 oraz na rysunku 11 stwierdzono, że zaczyny

\footnotetext{
${ }^{2}$ BWOW (z ang. by weight of water) - w stosunku do ilości wody.

${ }^{3}$ BWOC ( $\mathrm{z}$ ang. by weight of cement) - w stosunku do ilości cementu.
}

z dodatkiem mikrosfer (nr 11, 12, 13) najlepiej były opisywane modelem reologicznym Cassona. Zaczyn z dodatkiem perlitu (nr 14) odpowiadał natomiast modelowi reologicznemu Herschela-Bulkleya (tab. 4). Zaobserwowano, że najwyższą wartość granicy płynięcia opisywanej modelem Cassona (20,02 $\mathrm{Pa}$ ) posiadał zaczyn kontrolny zawierający mikrosferę glinokrzemianową. Natomiast zaczyn z dodatkiem 15\% mikrosfery szklanej H5 charakteryzował się najniższą wartością granicy płynięcia, która wynosiła 15,09 Pa (rys. 11). Zaczyny z dodatkiem mikrosfer glinokrzemianowych (zaczyn nr 11 i 12) posiadały najniższe wartości lepkości, które zawierały się w przedziale od $0,03 \mathrm{~Pa} \cdot \mathrm{s}$ do $0,04 \mathrm{~Pa} \cdot \mathrm{s}$. Natomiast zaczyny z dodatkiem mikrosfer szklanych i perlitu filtracyjnego, które to dodatki posiadają mocniejszy stopień rozdrobnienia, charakteryzowały się wyższymi lepkościami wynoszącymi od $0,06 \mathrm{~Pa} \mathrm{~s}$ do $0,08 \mathrm{~Pa} \cdot \mathrm{s}$ (rys. 11). Porównywalny trend zaobserwowano podczas interpretacji współczynnika konsystencji Herschela-Bulkleya, gdzie zaczyny z dodatkiem mocno rozdrobnionych frakcji posiadały wyższe wartości współczynnika konsystencji $\mathrm{H}_{\mathrm{HB}}$.

Analizując wpływ wybranych domieszek obniżających gęstość zaczynu na parametry mechaniczne stwardniałego zaczynu cementowego (tab. 5) zaobserwowano, że najwyższe wartości wczesnej wytrzymałości na ściskanie odnotowano dla 
zaczynu z dodatkiem mikrosfery CSF K (rys. 12). Uzyskane zawierających $3 \% \mathrm{CaCl}_{2}$ (rys. 9). Zaczyny z dodatkiem mocwyniki badań są potwierdzeniem wartości uzyskanych no rozdrobnionych frakcji mikrosfery szklanej (nr 13) oraz w przypadku badań zaczynów bazowych (cement-woda) perlitu (nr 14) charakteryzowały się niższymi wartościami

Tabela 4. Parametry reologiczne zaczynów cementowych

Table 4. Rheological parameters of cement slurries

\begin{tabular}{|c|c|c|c|c|c|}
\hline \multirow{2}{*}{ Model reologiczny } & \multirow{2}{*}{ Parametry reologiczne } & \multicolumn{4}{|c|}{ Zaczyn nr: } \\
\hline & & 11 & 12 & 13 & 14 \\
\hline \multirow{2}{*}{ Model Newtona } & Lepkość dynamiczna $[\mathrm{Pa} \cdot \mathrm{s}]$ & 0,1183 & 0,1373 & 0,1572 & 0,1917 \\
\hline & Współczynnik korelacji [-] & 0,4035 & 0,6761 & 0,8234 & 0,8111 \\
\hline \multirow{3}{*}{ Model Binghama } & Lepkość plastyczna $[\mathrm{Pa} \cdot \mathrm{s}]$ & 0,0744 & 0,0933 & 0,1157 & 0,1406 \\
\hline & Granica płynięcia [Pa] & 29,0419 & 29,1193 & 27,4662 & 33,7939 \\
\hline & Współczynnik korelacji [-] & 0,9838 & 0,9822 & 0,9898 & 0,9804 \\
\hline \multirow{3}{*}{ Model Ostwalda de Waele } & Współczynnik konsystencji $\left[\mathrm{Pa} \cdot \mathrm{s}^{\mathrm{n}}\right]$ & 12,6964 & 11,5680 & 9,3586 & 9,5457 \\
\hline & Wykładnik potęgowy [-] & 0,2718 & 0,3073 & 0,3598 & 0,3945 \\
\hline & Współczynnik korelacji [-] & 0,9516 & 0,9536 & 0,9606 & 0,9828 \\
\hline \multirow{3}{*}{ Model Cassona } & Lepkość Cassona $[\mathrm{Pa} \cdot \mathrm{s}]$ & 0,0303 & 0,0426 & 0,0608 & 0,0789 \\
\hline & Granica płynięcia [Pa] & 20,0188 & 18,7925 & 15,9032 & 18,1919 \\
\hline & Współczynnik korelacji [-] & 0,9946 & 0,9976 & 0,9992 & 0,9959 \\
\hline \multirow{4}{*}{ Model Herschela-Bulkleya } & Granica płynięcia [Pa] & 22,5816 & 21,8754 & 18,4856 & 16,3614 \\
\hline & Współczynnik konsystencji $\left[\mathrm{Pa} \cdot \mathrm{s}^{\mathrm{n}}\right]$ & 0,6336 & 0,6739 & 0,8335 & 2,0933 \\
\hline & Wykładnik potęgowy [-] & 0,6951 & 0,7183 & 0,7187 & 0,6174 \\
\hline & Współczynnik korelacji [-] & 0,9934 & 0,9968 & 0,9988 & 0,9980 \\
\hline
\end{tabular}

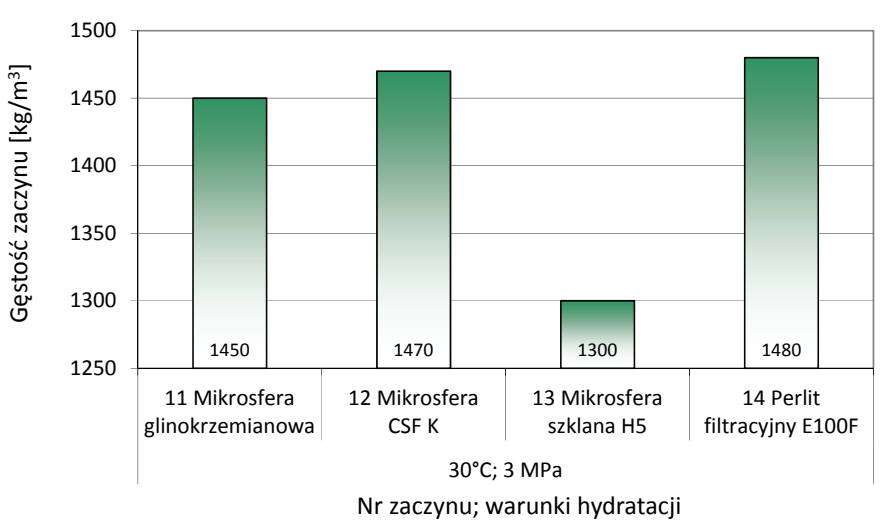

Rys. 10. Zestawienie gęstości zaczynów cementowych

Fig. 10. Summary of cement slurry density

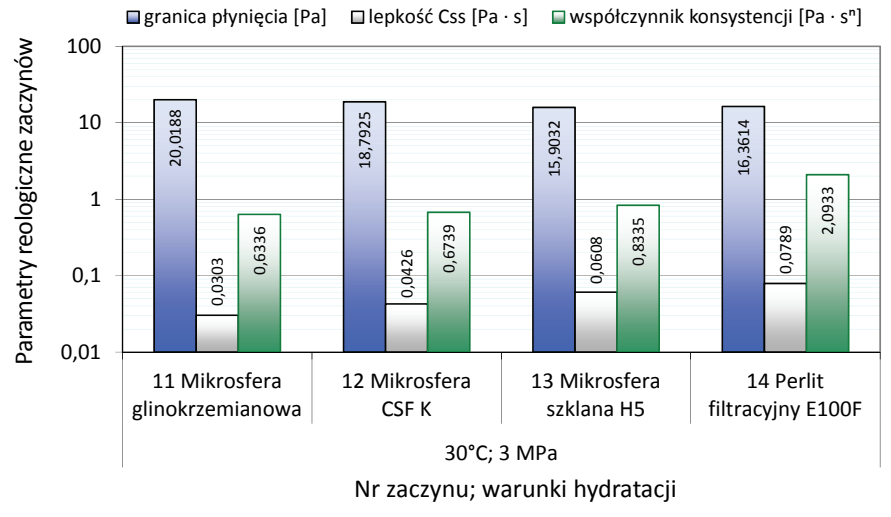

Rys. 11. Zestawienie wyników badań parametrów reologicznych zaczynów cementowych

Fig. 11. Summary of the results of the rheological parameters of cement slurries

Tabela 5. Parametry badanych zaczynów cementowych

Table 5. Parameters of cement slurries

\begin{tabular}{|c|c|c|c|c|c|c|c|c|}
\hline \multirow{3}{*}{ Nr zaczynu } & \multirow{3}{*}{$\begin{array}{l}\text { Gęstość } \\
{\left[\mathrm{kg} / \mathrm{m}^{3}\right]}\end{array}$} & \multicolumn{3}{|c|}{$\begin{array}{l}\text { Wytrzymałość na ściskanie z Ultrasonic } \\
\text { Cement Analyzer po czasie hydratacji }\end{array}$} & \multirow{3}{*}{$\begin{array}{c}\text { Czas osiągnięnia } \\
\text { wytrzymałości } \\
\text { 3,5 } \mathrm{MPa}\end{array}$} & \multirow{3}{*}{$\begin{array}{c}\text { Filtracja } \\
{\left[\mathrm{cm}^{3} / 30 \mathrm{~min}\right]}\end{array}$} & \multicolumn{2}{|c|}{$\begin{array}{l}\text { Czas gęstnienia } \\
\text { Czas dojścia }\end{array}$} \\
\hline & & $12 \operatorname{godz}$. & 24 godz. & $48 \operatorname{godz}$. & & & $30 \mathrm{Bc}$ & $100 \mathrm{Bc}$ \\
\hline & & \multicolumn{3}{|c|}{ [MPa] } & & & \multicolumn{2}{|c|}{ [godz:min] } \\
\hline 11 & 1450 & 2,0 & 5,0 & 8,0 & $15: 28$ & 194,0 & $5: 25$ & $6: 40$ \\
\hline 12 & 1470 & 4,0 & 8,0 & 12,0 & $9: 11$ & 201,0 & $5: 50$ & $7: 10$ \\
\hline 13 & 1300 & 3,0 & 6,0 & 9,0 & $10: 45$ & 279,0 & $5: 00$ & $5: 40$ \\
\hline 14 & 1480 & 3,0 & 5,0 & 7,0 & $12: 44$ & 241,0 & $6: 30$ & $7: 15$ \\
\hline
\end{tabular}


niż zaczyn kontrolny (nr 11). Należy zauważyć, że zadowalające rezultaty uzyskano stosując dodatek mikrosfery szklanej (zaczyn nr 13), ponieważ przy najniższej wartości gęstości $\left(1300 \mathrm{~kg} / \mathrm{m}^{3}\right)$ uzyskano wyższe wartości wczesnej wytrzymałości niż w przypadku zaczynu kontrolnego nr 11, którego gęstość była wyższa $\left(1450 \mathrm{~kg} / \mathrm{m}^{3}\right)$.

Porównując wartości filtracji zaczynów stwierdzono, że zaczyny zawierające dodatek mikrosfery glinokrzemianowej posiadały najniższe wartości filtracji zawierające się w zakresie od 194 do $201 \mathrm{~cm}^{3} / 30$ min (składy 11, 12; tab. 5). Z kolei zaczyny z dodatkiem mikrosfer szklanych i perlitu posiadały wyższe wartości filtracji (składy 13, 14; tab. 5). Mogło to być wynikiem zastosowania większej ilości środka dyspergującego. Przy czym dodatek $15 \%$ mikrosfery szklanej skutkował uzyskaniem największej wartości filtracji, która wynosiła $279 \mathrm{~cm}^{3} / 30 \mathrm{~min}$. Zaczyn z dodatkiem perlitu filtracyjnego posiadał natomiast filtrację wynoszącą $241 \mathrm{~cm}^{3} / 30 \mathrm{~min}$. Takie zachowanie można thumaczyć podwyższonym zapotrzebowaniem na wodę perlitu.

Podczas badania czasu gęstnienia zaczynów w warunkach otworopodobnych zaobserwowano, że najkrótszy z badanych zaczynów czas gęstnienia uzyskano $\mathrm{w}$ zaczynie $\mathrm{z}$ dodatkiem mikrosfer szklanych. Mocne wydłużenie wartości czasu gęstnienia w porównaniu do próbki kontrolnej uzyskano natomiast dla zaczynu z dodatkiem 15\% perlitu filtracyjnego E100F (rys. 13).

W trakcie badania czasu uzyskania minimalnej wartości wytrzymałości mechanicznej (równej 3,5 MPa) zaobserwowano, że wszystkie z badanych wypełniaczy lekkich powodują skrócenie czasu niezbędnego do uzyskania wartości wytrzymałości 3,5 MPa przez próbkę. Jednak najskuteczniejsze działanie widoczne było $\mathrm{w}$ zaczynie $\mathrm{z}$ dodatkiem mikrosfery CSF K. Uzyskano czas 9 godzin 11 minut w porównaniu do wartości wynoszącej 15 godz. 28 minut dla próbki kontrolnej (rys. 13).

Analizując uzyskane wyniki stwierdzano, że poddane badaniom lekkie materiały wypełniające wykazują mocny wpływ na wybrane parametry zaczynu cementowego, co nie jest bez znaczenia podczas projektowania receptur zaczynów o obniżonej gęstości. Takie zachowanie zaczynów pod wpływem wybranych dodatków jest szczególnie istotne w przypadku zaczynów lekkich, ponieważ regulowanie parametrów tego rodzaju zaczynów bardzo często wiąże się ze znacznym obniżeniem jego stabilności sedymentacyjnej. Nadmierne frakcjonowanie jest niedopuszczalne, ponieważ może skutkować brakiem szczelności oraz migracji gazu. Dlatego też zagadnienie dotyczące wpływu badanych domieszek obniżających gęstość zaczynu na wybrane parametry zaczynu cementowego powinno być weryfikowane na podstawie badań laboratoryjnych, dzięki czemu wpływ wybranego środka na parametry zaczynu będzie bardziej przewidywalny.

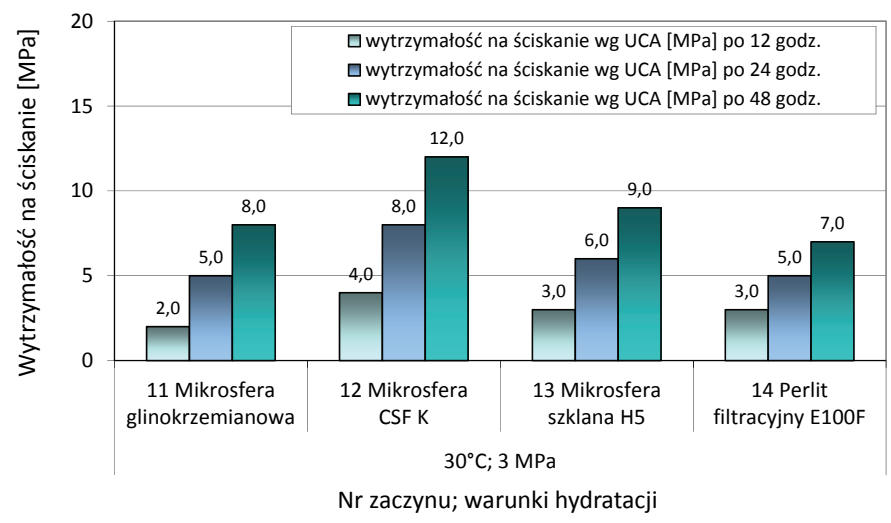

Rys. 12. Zestawienie wytrzymałości na ściskanie próbek z zaczynów cementowych po 12, 24 oraz 48 godzinach hydratacji - pomiar w Ultrasonic Cement Analyzer

Fig. 12. Comparison of compressive strength of cement slurries samples after 12, 24 and 48 hours of hydration - measured by Ultrasonic Cement Analyzer

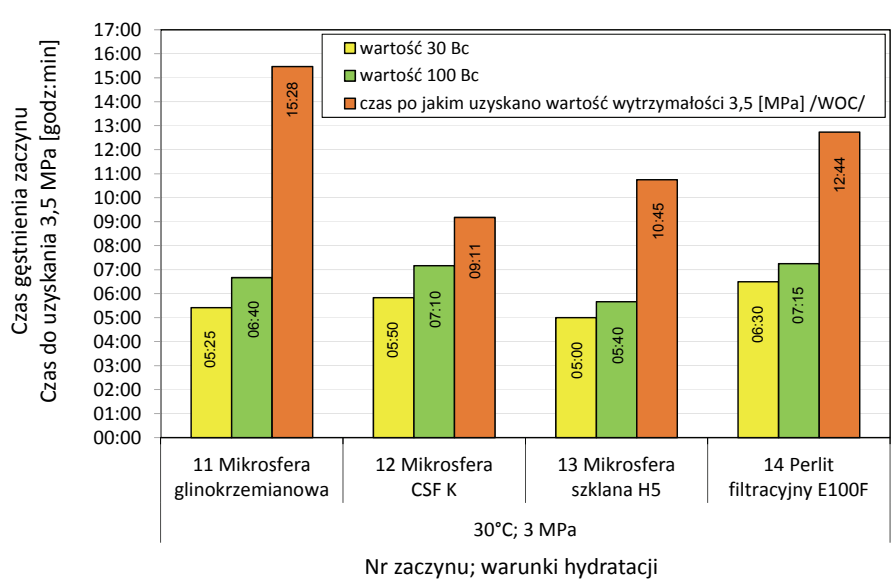

Rys. 13. Zestawienie wartości czasu gęstnienia zaczynów cementowych oraz czasu do uzyskania przez próbkę wartości 3,5 $\mathrm{MPa}$ (WOC - waiting on cement)

Fig. 13. Summary of cement slurry thickening time values and the time until the sample reaches $3.5 \mathrm{MPa}$ (WOC - waiting on cement)

\section{Wnioski}

Na podstawie zrealizowanych prac badawczych określających wpływ wybranych domieszek obniżających gęstość na parametry zaczynu cementowego sformułowano następujące wnioski końcowe:

- obecność domieszki lekkich frakcji w recepturze zaczynu cementowego powodowała skrócenie jego czasu wiązania w recepturach bazowych ${ }^{4}$ zawierających $1,5 \%$ chlorku wapnia;

- wprowadzenie lekkich frakcji do zaczynu cementowego skutkowało wzrostem wytrzymałości mechanicznej

${ }^{4}$ Receptura bazowa - na potrzeby publikacji recepturą bazową oznaczono zaczyn, w skład którego wchodzi tylko cement $\mathrm{i}$ woda. 
w zaczynie zawierającym $1,5 \% \mathrm{CaCl}_{2}$ (wyjątek stanowiła mikrosfera glinokrzemianowa, której obecność powodowała obniżenie wartości wytrzymałości);

- najmocniejszy przyrost wytrzymałości na ściskanie w zaczynie bazowym zawierającym $1,5 \% \mathrm{CaCl}_{2}$ odnotowano po wprowadzeniu domieszki perlitu filtracyjnego E100F oraz mikrosfery szklanej H5;

- wzrost koncentracji chlorku wapnia w zaczynie bazowym z wartości $1,5 \%$ do $3 \%$ powodował osłabienie działania przyspieszającego wiązanie zaczynu pod wpływem obecności domieszek lekkich;

- zastosowanie 3\%-owej koncentracji chlorku wapnia w zaczynie bazowym obniżało intensywność wzrostu wytrzymałości na ściskanie pod wpływem domieszki mikrosfery szklanej H5 oraz domieszki perlitu filtracyjnego E100F;

- obecność mikrosfery szklanej H5 powodowała najmocniejsze obniżenie gęstości, co jest korzystne z ekonomicznego punktu widzenia, ponieważ istnieje możliwość zastosowania mniejszej ilości przy jednoczesnym uzyskaniu porównywalnej wartości gęstości zaczynu zawierającego większą ilość mikrosfery glinokrzemianowej;

- zaczyny z dodatkiem mikrosfer (nr 11, 12, 13) pod względem reologicznym były najlepiej opisywane modelem reologicznym Cassona. Zaczyn z dodatkiem perlitu (nr 14) odpowiadał natomiast modelowi reologicznemu Herschela-Bulkleya;

- zaczyny z mikrosferami glinokrzemianowymi posiadały niższe wartości lepkości $\mathrm{C}_{\mathrm{ss}}$ niż zaczyny z dodatkiem mikrosfer szklanych oraz z dodatkiem perlitu. Może być to wynikiem mocnego rozdrobnienia zarówno mikrosfery szklanej jak i perlitu filtracyjnego, co wpływa na wzrost lepkości zaczynu;

- najwyższe wartości wczesnej wytrzymałości na ściskanie odnotowano dla zaczynu z dodatkiem mikrosfery glinokrzemianowej CSF K;

- dodatek 15\% mikrosfery szklanej H5 skutkował uzyskaniem największej wartości filtracji, co mogło być wynikiem większej ilości środka dyspergującego w zaczynie, a jednocześnie brakiem właściwości sorpcyjnych mikrosfery szklanej H5;

- wprowadzenie mikrosfer szklanych H5 do receptury zaczynu spowodowało skrócenie czasu gęstnienia. Z kolei obecność perlitu filtracyjnego E100F powodowała wydłużenie wartości czasu gęstnienia analizowanych zaczynów.

Artykuł powstał na podstawie pracy badawczej pt.: Analiza możliwości doszczelnienia mikrostruktury płaszcza cementowego za pomoca nowych domieszek drobnoziarnistych - praca INiG - PIB na zlecenie MNiSW, nr archiwalny: DK-4100-0034/2019, nr zlecenia: 0044/KW/2019.

\section{Literatura}

Bayu S., Muhammed T.F., Roby T., 2010. Effect of lignosulfonate and temperature on compressive strength of cement. Proceedings of World Geothermal Congress, Bali, Indonesia: 1-3.

Bensted J., 2004. Cementy wiertnicze. Cz. 2. Stosowanie cementów wiertniczych do cementowania odwiertów. Cement Wapno Beton, 2: 61-72.

Falode O.A., Salam K.K., Arinkoola, A.O., Ajagbe B.M., 2013. Prediction of compressive strength of oil field class $\mathrm{G}$ cement slurry using factorial design. Journal of Petroleum Exploration and Production Technology, 3(4): 297-302.

Herianto A., Fathaddin M.T., 2005. Effects of additives and conditioning time on comprehensive and shear bond strengths of geothermal well cement. Proceedings of World Geothermal Congress. Antalya, Turkey: 1-7.

Jordan A., Pernites R., Albrighton L., 2018. Low-density, lightweight cement tested as alternative to reduce lost circulation, achieve desired top of cement in long horizontal wells. Drillingcontactor, September/October: 62-64.

Kremieniewski M., 2017a. Poprawa stabilności sedymentacyjnej zaczynu cementowego. Nafta-Gaz, 4: 242-249. DOI: 10.18668/ NG.2017.04.04

Kremieniewski M., 2017b. Wpływ perlitu pylistego na własności technologiczne zaczynu cementowego. Nafta-Gaz. 12: 943-952. DOI 10.18668/NG.2017.12.05.

Kremieniewski M., 2018. Poprawa wczesnej wytrzymałości mechanicznej płaszcza cementowego powstałego z zaczynu lekkiego. Nafta-Gaz, 8: 599-605. DOI: 10.18668/NG.2018.08.06.

Kremieniewski M., 2019a. Receptury zaczynów do uszczelniania kolumn rur posadowionych w otworach wierconych w skałach chłonnych. Nafta-Gaz, 8: 451-457. DOI: 10.18668/NG.2019.08.01.

Kremieniewski M., 2019b. Rola plastyfikatora w projektowaniu zaczynu lekkiego o podwyższonej stabilności sedymentacyjnej. Nafta-Gaz, 9: 571-578. DOI: 10.18668/NG.2019.09.06.

Kremieniewski M., 2019c. Korelacja wyników badań filtracji i wczesnej wytrzymałości mechanicznej zaczynów cementowych z dodatkiem mączki krzemionkowej. Nafta-Gaz, 7: 394-403. DOI 10.18668/NG.2019.07.03

Kremieniewski M., 2019d. Korelacja wyników badań wytrzymałości na ściskanie i przyczepności do rur stalowych płaszcza cementowego z zaczynu o obniżonej gęstości. Nafta-Gaz, 10: 613-624. DOI:10.18668/NG.2019.10.03.

Kremieniewski M., 2019e. Wpływ drobnoziarnistej krzemionki na parametr czasu oczekiwania na cement - WOC. Nafta-Gaz, 11: 683-690. DOI: 10.18668/NG.2019.11.03.

Kremieniewski M., Kędzierski M., 2019. Badanie frakcjonowania lekkich materiałów obniżających gęstość jako wstepnego parametru podczas projektowania receptury zaczynu lekkiego. Nafta-Gaz, 12: 35-42. DOI: 0.18668/NG.2019.12.04.

Kremieniewski M., Rzepka M., 2016. Przyczyny i skutki przepływu gazu w zacementowanej przestrzeni pierścieniowej otworu wiertniczego oraz metody zapobiegania temu zjawisku. NaftaGaz, 9: 722-728.

Kremieniewski M., Stryczek S., 2019. Zastosowanie cementu wysokoglinowego do sporządzania zaczynów uszczelniających w technologiach wiertniczych. Cement Wapno Beton, 3: 215-226.

Kremieniewski M., Stryczek S., Wiśniowski R., Rzepka M., Gonet A., 2017. Wpływ dodatku montmorylonitu /bentonitu/ na parametry świeżego i stwardniałego zaczynu cementowego. AGH Drilling, Oil, Gas, 34: 323-334.

Kudowski W., 2010. Chemia cementu i betonu. Wydawnictwo Naukowe PWN, Warszawa: 1-700. 
Nelson E.B. (ed.), 1990. Well Cementing, Schlumberger Educational Service, Houston, Teksas, USA.

Peng, Ya, Jacobsen S., 2013 Influence of water/cement ratio, admixtures and filler on sedimentation and bleeding of cement paste. Cement and Concrete Research, 54: 133-142 DOI: 10.1016/j. cemconres.2013.09.003

Półchłopek T. (kier. zespołu), 1993. Zaczyny cementowe do cementowania otworów kierunkowych i poziomych oraz technologia ich zatłaczania. Praca INiG; Archiwum Instytutu Nafty i Gazu -Państwowego Instytutu Badawczego, Kraków.

Raczkowski J., Stryczek S., Fugiel K., Kraj Ł., Wilk S., 1978. Zaczyny do uszczelniania w otworach wiertniczych. Skrypty uczelniane Akademia Górniczo-Hutnicza: 1-311.

Rzepka M., Kremieniewski M., Dębińska E., 2012. Zaczyny cementowe przeznaczone do uszczelniania eksploatacyjnych kolumn rur okładzinowych na Niżu Polskim. Nafta-Gaz, 8: 512-522.

Rzepka M., Stryczek S.: 2008. Laboratoryjne metody określania parametrów technologicznych świeżych zaczynów uszczelniających przed zabiegiem związanym z procesem uszczelniania kolumn rur okładzinowych w otworach wiertniczych. Wiertnictwo, Nafta-Gaz, 25/2. 625-636.

Stryczek S., Gonet A., Wiśniowski R., 2005. Wpływ wybranego dodatku mineralnego na własności technologiczne zaczynów cementowych. Wiertnictwo, Nafta, Gaz, 22/1: 333-341.

Stryczek S., Wiśniowski R., Gonet A., Ferens W., 2009. Parametry reologiczne świeżych zaczynów uszczelniających w zależności od czasu ich sporządzania. Wiertnictwo, Nafta, Gaz, 26/1-2: 369-382.

Stryczek S., Wiśniowski R., Gonet A., Złotkowski A., 2014. The influence of time of rheological parameters of fresh cement slurries. AGH Drilling, Oil, Gas, 31: 123-133. DOI 10.7494/ drill.2014.31.1.123.

Stryczek S., Wiśniowski R., Uliasz-Misiak B., Złotkowski A., Kotwica Ł., Rzepka M., Kremieniewski M., 2016. Studia nad doborem zaczynów uszczelniających w warunkach wierceń w basenie pomorskim. Wydawnictwo AHG, Kraków.

Uliasz B. M., Dubiel S., 2015. Problemy rekonstrukcji odwiertów geotermalnych. Przegląd Górniczy, 7: 55-61.

Wiśniowski R., Stryczek S., Skrzypaszek K., 2007. Kierunki rozwoju badań nad reologią płynów wiertniczych. Wiertnictwo, Nafta, Gaz, 24: 595-607.

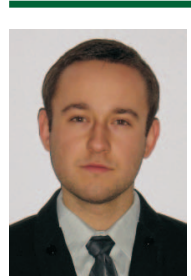

Dr inż. Marcin KREMIENIEWSKI

Adiunkt w Zakładzie Technologii Wiercenia Instytut Nafty i Gazu - Państwowy Instytut Badawczy ul. Lubicz 25 A

31-503 Kraków

E-mail: marcin.kremieniewski@inig.pl

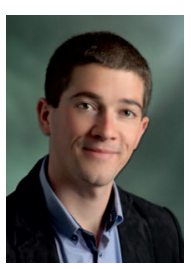

Mgr inż. Miłosz KĘDZIERSKI

Specjalista inżynieryjno-techniczny w Zakładzie

Technologii Wiercenia

Instytut Nafty i Gazu - Państwowy Instytut Badawczy ul. Lubicz $25 \mathrm{~A}$

31-503 Kraków

E-mail: milosz.kedzierski@inig.pl

\section{OFERTA BADAWCZA ZAKŁADU ANALIZ NAFTOWYCH}

- ropa naftowa i jej przerób:

» kompleksowe analizy rop naftowych dla potrzeb optymalizacji przerobu,

" wyznaczanie optymalnych parametrów procesu destylacij produktów odpadowych,

" optymalizacja pracy weztów odsalania i wezłów aminowych;

daktyloskopia chemiczna - realizacja złożonych zadań, wymagających identyfikacji przyczyn problemu technicznego, z zastosowaniem metod analizy chemicznej:

» badania identyfikacyjne osadów i zanieczyszczeń w zbiornikach magazynowych, cysternach, na instalacjach przemystowych, w rurociaggach i wymiennikach ciepta,

» ustalanie źródet pochodzenia osadów powstałych w trakcie eksploatacii maszyn, urządzeń i pojazdów.

» identyfikacja i oznaczanie niepożądanych substancji w mediach ciektych i gazowych,

" analiza parametrów procesowych oraz wsadów stosowanych na instalacjach w korelacji z tworzeniem się osadów, w tym z wykorzystaniem sieci neuronowych,

» ustalanie pochodzenia rozlewów, wylewów i zanieczyszczeń substancjami typu węglowodorów,

" badanie źródet naptywów do wód chtodniczych,

" optymalizacja pracy węztów usuwania węglowodorów ze ścieków:

kawerny solne - testy symulacyjne przechowywania rop i paliw;

chemia analityczna branży naftowej, w tym produktów pochodzenia biogennego:

» opracowywanie/walidacja nowych metod badań produktów,

" badania jakościowe produktów naftowych i pokrewnych, świeżych i z eksploatacii (certyfikat akredytacji AB 009); badania i doradztwo w zakresie Nomenklatury Scalonej CN;

orzecznictwo i opinie o jakości paliw i ptynów eksploatacyinych, środków smarowych samochodowych i przemystowych oraz innych produktów naftowych, biopaliw, biokomponentów.

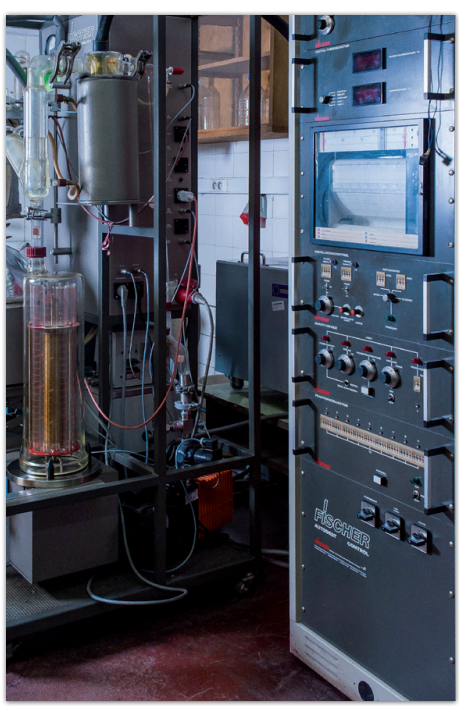

INSTYTUT NAFTY I GAZU

- Państwowy Instytut Badawczy 